\title{
Fuels derived from starch digestion have different effects on energy intake and metabolic responses of cows in the postpartum period
}

\author{
Laura B. Gualdrón-Duarte and Michael S. Allen ${ }^{1}$ \\ Department of Animal Science, Michigan State University, East Lansing 48824-1225
}

\begin{abstract}
Absorbed fuels from the digestion of starch include propionic acid (PA) produced by ruminal fermentation and glucose (GLU) from intestinal digestion, which may be partially metabolized to lactic acid (LA) by intestinal tissues. Our objective was to evaluate the effects of these fuels on dry matter intake (DMI) and feeding behavior of cows in the postpartum period. We hypothesized that these fuels affect feed intake differently and that their effects are related to differences in their hepatic metabolism. Glucose was expected to have little effect on feed intake because little or no GLU is extracted from the blood by the liver. Whereas both LA and PA are anaplerotic and can stimulate oxidation of acetyl CoA in hepatocytes, hepatic extraction of PA is greater than LA, which depends on cytosolic redox state. Continuous isoenergetic infusions (150 $\mathrm{kcal}$ of ME/h) of PA, LA, or GLU or no infusion were administered abomasally to 8 ruminally cannulated multiparous Holstein cows (12.4 \pm 6.2 d postpartum) in a duplicate $4 \times 4$ Latin square design experiment, with four 1-d infusion periods, balanced for carry-over effects. Treatment sequences were assigned to cows randomly, and treatments included control $(\mathrm{CON}$, no infusion), PA (0.41 mol/h), LA $(0.46 \mathrm{~mol} / \mathrm{h})$, and GLU $(0.22 \mathrm{~mol} / \mathrm{h})$. Solutions containing treatments were infused at $500 \mathrm{~mL} / \mathrm{h}$ for $22 \mathrm{~h} / \mathrm{d}$ and provided $\sim 3.3$ $\mathrm{Mcal} / \mathrm{d}$. Feeding behavior was recorded by a computerized data acquisition system. Gross energy digestibility of the diet was determined for each cow and used to calculate metabolizable energy intake (MEI) from the diet. Total MEI was calculated as the sum of MEI from the diet plus energy from infusions. Data were analyzed statistically with a mixed model including the fixed effect of treatment and random effects of block and cow within block. Each treatment was compared with CON by contrasts. Compared with CON, PA decreased DMI by $24 \%$ (14.3 vs. $18.9 \mathrm{~kg} / \mathrm{d}$ ) and total MEI by
\end{abstract}

Received July 31, 2017.

Accepted January 14, 2018.

${ }^{1}$ Corresponding author: allenm@msu.edu
$13 \%$ (34.8 vs. $40.2 \mathrm{Mcal} / \mathrm{d}$ ) with a tendency to decrease meal frequency. Lactic acid decreased DMI by $14 \%$ (16.3 vs. $18.9 \mathrm{~kg} / \mathrm{d}$ ) compared with CON by decreasing meal size $20 \%$ but did not affect MEI. Glucose infusion did not affect DMI or MEI. Treatment effects on DMI and MEI were consistent with their expected effects on hepatic oxidation. Depression of feed intake in diets containing highly fermentable starch is likely because of differences in hepatic metabolism.

Key words: appetite, hepatic oxidation theory, metabolic fuels

\section{INTRODUCTION}

Cereal grains high in starch are included in rations to meet dietary energy requirements of high-producing dairy cows. However, highly fermentable starch sources can depress feed intake compared with less fermentable starch sources (Allen, 2000). High-moisture corn decreased DMI $8 \%$ for mid-lactation cows (Oba and Allen, 2003a) and $11 \%$ for cows in the postpartum (PP) period (Albornoz and Allen, 2016), compared with the less fermentable dry ground corn. Ruminal fermentability of starch varies greatly from $\sim 30 \%$ to $\sim 90 \%$ (Allen, 2000) depending upon genetics, maturity, processing, and storage method of the starch source (Kotarski et al., 1992; Larson and Hoffman, 2008). This wide variation affects the type and supply of fuels available for absorption including propionic acid from ruminal fermentation, glucose from enzymatic hydrolysis of starch that passed from the rumen to the small intestine, and lactic acid from the partial metabolism of glucose by enterocytes. Once absorbed, metabolism of these fuels varies with different efficiencies of extraction from the blood by the liver and potential of stimulating hepatic oxidation. According to the hepatic oxidation theory (HOT) of the control of feed intake, anaplerotic fuels extracted by the liver may promote oxidation of acetyl CoA (AcCoA) contributing to satiety (Allen et al., 2009). Of the primary fuels absorbed from starch digestion in ruminants, propionate and lactate are anaplerotic, whereas little glucose is extracted from the blood by the liver. However, hepatic extraction of propionate 
from the blood is greater than lactate (Reynolds et al., 2003), which is dependent upon cytosolic redox state in the hepatocyte (Allen et al., 2009). The objective of this experiment was to evaluate the short-term effects of fuels derived from fermentation and digestion of starch on DMI and feeding behavior of cows in the PP period. We hypothesized that these fuels differ in their effects on DMI and ME intake (MEI) and that their effects are consistent with their ability to stimulate hepatic oxidation.

\section{MATERIALS AND METHODS}

\section{Animals, Housing, and Care}

All experimental procedures were approved by the Institutional Animal Care and Use Committee at Michigan State University, East Lansing. Cows were ruminally cannulated at least $45 \mathrm{~d}$ before expected calving date. Each cow was housed in the same individual tiestall for the duration of the experiment. Cows were fed once daily $(1200 \mathrm{~h})$ at $125 \%$ of expected intake and milked in their stalls twice daily at 0530 and $1730 \mathrm{~h}$.

\section{Experimental Design, Diets, and Treatments}

Eight multiparous Holstein cows (12.4 \pm 4.2 d PP) at the Michigan State University Dairy Teaching and Research Center were used in a duplicated $4 \times 4$ Latin square design with 2 squares of cows with 4 cows each. Cows within each square were randomly assigned to treatment sequence. The squares were conducted at different times because of cow availability and are therefore referred to as blocks. Cows were blocked by date of parturition; the first block was conducted during March 2015 and the second during October 2015. Each block was conducted over an 8-d period with 4 infusion days separated by a washout day. Abomasal infusion devices were placed in each cow at least $2 \mathrm{~d}$ before start the infusion treatments and remained in place for the duration of the experiment. Placement was verified at the beginning and end of each infusion day. All cows received a common experimental diet from parturition through the end of the experiment. The experimental diets (Table 1) were formulated to meet or exceed estimated requirements for cows according to NRC (2001) and fed as a TMR.

Treatments were propionic acid (PA; food grade, 99.5\%, Kemin Industries Inc., Des Moines, IA), L-lactic acid (LA; food grade 88.0\%, Sena International Inc., Polo, IL), and glucose (GLU; $\geq 99.5 \%$, Sigma Aldrich, Chemical Co., St. Louis, MO) infused continuously into the abomasum, and control (CON; no infusion). Isoenergetic amounts of PA $(0.41 \mathrm{~mol} / \mathrm{h}), \mathrm{LA}(0.46 \mathrm{~mol} / \mathrm{h})$, and GLU $(0.22 \mathrm{~mol} / \mathrm{h})$ dissolved in distilled water were infused at a rate of $508 \mathrm{~mL} / \mathrm{h}$ for $22 \mathrm{~h} / \mathrm{d}$, providing 3.26 Mcal of ME/d (148 kcal/h), which is approximately $10 \%$ of daily MEI by cows in the PP period. Rate of infusion was selected based on previous studies in which PA decreased DMI of cows in the PP period compared with acetic acid (Oba and Allen, 2003b; Stocks and Allen, 2012). Metabolizable energy content of treatments were assumed to equal their gross energy of $365.0 \mathrm{kcal} /$ mol for PA (Labedeva, 1964), $321.2 \mathrm{kcal} / \mathrm{mol}$ for LA (Saville and Gundry, 1959), and $673.4 \mathrm{kcal} / \mathrm{mol}$ (Emery and Benedict, 1911) for GLU. Solutions were infused into the abomasum using Baxter Flo-Gard 6201 infusion pumps (Baxter Medical Products, Deerfield, IL) through vinyl tubing $(0.95 \mathrm{~cm}$ o.d., $0.71 \mathrm{~cm}$ i.d.) connected to a Nalgene bottle $(3.8 \mathrm{~cm}$ diameter, $8.5 \mathrm{~cm}$ long) held in place with a rubber disk as described in Gualdrón-Duarte and Allen (2017).

\section{Data and Sample Collection}

Cows were withheld from feed from 1000 to $1200 \mathrm{~h}$ daily, and the amount of feed offered and orts were weighed for each cow daily. Samples $(0.5 \mathrm{~kg})$ of all dietary ingredients and the TMR were collected daily throughout the experiment, and orts for each cow were collected at the end of each infusion day and stored in plastic bags at $-20^{\circ} \mathrm{C}$ until processed. Feeding behavior data (feed disappearance and water intake) were recorded continuously for $22 \mathrm{~h}$ daily for each cow during infusions via computer every $5 \mathrm{~s}$, and size, length, and frequency of meals, intermeal interval, total eating

Table 1. Ingredients and nutrient composition of diets fed for blocks 1 and 2

\begin{tabular}{lcc}
\hline Item & Block 1 & Block 2 \\
\hline Ingredient, \% of DM & & \\
Corn silage & 39.6 & 33.8 \\
Soybean meal & 16.1 & 15.9 \\
Alfalfa silage & 14.1 & 5.54 \\
Ground corn & 10.4 & 17.8 \\
Alfalfa hay & 9.9 & 9.7 \\
Soybean hulls & 5.7 & 5.5 \\
Grass silage & - & 7.6 \\
Vitamin and mineral mix & 4.2 & 4.1 \\
Nutrient composition & & \\
DM, \% & 51.0 & 55.0 \\
Starch, \% of DM & 19.8 & 22.0 \\
NDF, \% of DM & 35.1 & 34.2 \\
Forage NDF, \% of DM & 29.5 & 27.5 \\
CP, \% of DM & 16.6 & 16.0 \\
\hline
\end{tabular}

${ }^{1}$ Vitamin and mineral mix contained $25.6 \% \mathrm{NaCl}, 10.0 \% \mathrm{Ca}, 2.0 \mathrm{Mg}$, $2.0 \% \mathrm{P}, 30 \mathrm{mg} / \mathrm{kg}$ of Co, $506 \mathrm{mg} / \mathrm{kg}$ of $\mathrm{Cu}, 20 \mathrm{mg} / \mathrm{kg}$ of I, $2,220 \mathrm{mg}$ / $\mathrm{kg}$ of $\mathrm{Fe}, 2,080 \mathrm{mg} / \mathrm{kg}$ of $\mathrm{Mn}, 15 \mathrm{mg} / \mathrm{kg}$ of Se, $2,030 \mathrm{mg} / \mathrm{kg}$ of Zn, $300 \mathrm{kUI} / \mathrm{kg}$ of vitamin $\mathrm{A}, 50 \mathrm{kIU} / \mathrm{kg}$ of vitamin D, $1,500 \mathrm{kIU} / \mathrm{kg}$ of vitamin E. 
time, and water intake were calculated (Dado and Allen, 1995).

Milk yield was recorded daily at each milking, and milk samples were collected from each milking and stored with preservative (Bronopol tablet, D\&F Control Systems, San Ramon, CA) at $4^{\circ} \mathrm{C}$. Milk samples were analyzed for fat, true protein, lactose, SCC, and milk urea nitrogen by Michigan DHIA (AOAC International, 1997).

Fecal samples were collected every $6 \mathrm{~h}$ for $24 \mathrm{~h}(\mathrm{n}=$ 4) during each day following infusion days and frozen at $-20^{\circ} \mathrm{C}$ for later analysis to determine diet digestibility for each cow for the entire experiment. Blood was sampled every day at the beginning and end of each infusion period from coccygeal vessels and collected into 4 evacuated tubes, 3 containing $\mathrm{K}_{2}$ EDTA and 1 containing potassium oxalate with $\mathrm{NaF}$ as a glycolytic inhibitor, and placed on ice until centrifugation. Tubes were centrifuged at $3,000 \times g$ for 15 min at $5^{\circ} \mathrm{C}$ immediately after sample collection. A 1-mL aliquot of plasma from each potassium EDTA tube was stored with 0.05 $M$ benzamidine (final concentration) to prevent enzymatic degradation of glucagon. Plasma was harvested and frozen at $-20^{\circ} \mathrm{C}$ until analysis. Liver samples were collected by needle biopsy (Bradford and Allen, 2005) between 1100 and $1200 \mathrm{~h}$ (before feeding) before each infusion and at the end of infusions for each period for analysis of hepatic AcCoA content. Samples were flash frozen in liquid nitrogen and stored on dry ice for transportation. Samples were stored at $-80^{\circ} \mathrm{C}$ until further analysis.

\section{Analysis of Samples}

Feed ingredients, orts, and fecal samples were dried in a $55^{\circ} \mathrm{C}$ forced-air oven for $72 \mathrm{~h}$ and analyzed for DM concentration. All samples were ground with a Wiley mill (1-mm screen, Arthur H. Thomas, Philadelphia, PA). Samples were analyzed for ash, NDF, indigestible NDF, CP, and starch. Feces were composited by cow by day on an equal DM basis before analysis. All nutrients are expressed as percentages of DM that was determined by drying at $105^{\circ} \mathrm{C}$ in a forced-air oven for more than $8 \mathrm{~h}$. Ash content was determined after $6 \mathrm{~h}$ of oxidation at $500^{\circ} \mathrm{C}$ in a muffle furnace. Crude protein was determined according to Hach et al. (1987). Starch was analyzed using an enzymatic method to hydrolyze it to glucose (Karkalas, 1985) after samples were gelatinized with sodium hydroxide; glucose concentration was measured by a glucose oxidase method (Sigma Chemical Co., St. Louis, MO). Content of NDF was analyzed according to Mertens (2002) with the inclusion of amylase and $\mathrm{Na}$ sulfite. Indigestible NDF was determined as NDF residue after $240 \mathrm{~h}$ of in vitro fermentation
(Goering and Van Soest, 1970). Ruminal fluid was collected from a nonpregnant fistulated dry cow and flasks were re-inoculated at $120 \mathrm{~h}$ to ensure microbes were viable. Indigestible NDF was used to estimate fecal output and apparent total-tract digestibility (Cochran et al., 1986). All samples were analyzed for gross energy by bomb calorimeter according to the manufacturer's instructions (Parr Instrument Inc., Moline, IL). Digestible energy intake, MEI from the diet, and total MEI were calculated following the procedure described in Gualdrón-Duarte and Allen (2017).

Plasma samples were analyzed using commercial kits for concentration of nonesterified fatty acids (NEFA; NEFA HR kit, Wako Chemicals USA, Richmond, VA) and BHB (kit no. 2240, Stanbio Laboratory, Boerne, TX). Triglycerides were analyzed with a commercial kit (L-type Triglyceride M, Wako Chemicals USA), modifying the quantity of sample used $(40 \mu \mathrm{L})$. Insulin was determined using an ELISA kit (kit no. 10-1201-01, Mercodia, Uppsala, Sweden). Plasma concentration of metabolites were analyzed colorimetrically with a microplate reader (SpectraMax Plus 384, Molecular Devices Corp., Sunnyvale, CA) Plasma glucagon concentration was determined using a RIA kit (kit no. GL32K, Linco Research Inc., St. Charles, MO). Plasma propionate and lactate concentrations were analyzed by HPLC (Waters Corp., Milford, MA). Plasma (600 $\mu \mathrm{L})$ was mixed with $600 \mu \mathrm{L}$ of $\mathrm{Ca}(\mathrm{OH})_{2}$ and $300 \mathrm{~mL}$ of $\mathrm{CuSO}_{4}$ containing crotonic acid as an internal marker in 1.7-mL microcentrifuge tubes. Samples were frozen, thawed, and centrifuged at $12,000 \times g$ for $10 \mathrm{~min}$ at $4^{\circ} \mathrm{C}$, and supernatant $(1,000 \mu \mathrm{L})$ was mixed with 42 $\mu \mathrm{L}$ of $\mathrm{H}_{2} \mathrm{SO}_{4}$ in 1.5-mL microcentrifuge tubes. Samples were frozen and thawed twice, and centrifuged at $12,000 \times g$ for $10 \mathrm{~min}$ at $4^{\circ} \mathrm{C}$ to precipitate and remove protein. Supernatant was transferred to HPLC vials. The column used was Aminex HPX-87H (catalog number 125-0140; $300 \times 7.8 \mathrm{~mm}$; Bio-Rad Laboratories, Richmond, CA). Column temperature was $50^{\circ} \mathrm{C}$, and the solvent was $0.015 \mathrm{~N} \mathrm{H}_{2} \mathrm{SO}_{4}$. Detection was by refractive index (Waters 410, Millipore Corp., Billerica, MA). Liver acetyl CoA was determined by HPLC following the King and Reiss (1985) procedure with modifications by Stocks and Allen (2012). Liver AcCoA content was expressed per gram of wet liver.

\section{RNA Extraction and Real-Time Quantitative PCR}

Total RNA was extracted from $\sim 15 \mathrm{mg}$ of hepatic tissue using the RSC simply RNA Tissue Kit (Promega Corp., Madison, WI) and then purified using the RQ1 RNase-Free DNase Kit (Promega Corp.). Purity, concentration, and integrity of mRNA were evaluated using a NanoDrop 1000 spectrophotometer (Thermo 
Scientific, Wilmington, DE) and an Agilent Bioanalyzer 2100 (Agilent Technologies, Santa Clara, CA) system. All samples had a RNA integrity number $>6$. Conversion to cDNA was performed using the Applied Biosystems High Capacity cDNA Archive Kit (Applied Biosystems, Foster City, CA).

\section{Quantitative PCR Analysis}

Gene expression of predetermined genes was determined using real-time quantitative PCR, and primers were designed using Primer Express 3.0 (Life Technologies Corp.) and Lasergene 9 core suite software (DNASTAR) and synthesized commercially (Integrated DNA Technologies, Coralville, IA). Primer sequences and accession numbers are summarized in Supplemental Table S1 (https://doi.org/10.3168/jds.2017-13607). Complementary DNA was synthesized from $100 \mathrm{ng}$ of total RNA as a template using the High-Capacity cDNA Reverse-Transcription Kit (Life Technologies Corp.), and amplification efficiency was validated for endogenous control and target genes with polled cDNA from samples using a 5-fold dilution series. A non-reverse-transcriptase control sample validated the absence of genomic DNA.

For relative gene expression, samples were assayed in triplicate on the Wafergen Smartchip System (WaferGen Biosystems, Fremont, CA) using cDNA at a primer-efficient concentration of $500 \mathrm{pg} / \mu \mathrm{L}$ and $10 \mu \mathrm{L}$ of Power SYBR Green (Life Technologies Corp.), $10 \mu \mathrm{L}$ of a forward and reverse primer mix $(1 \mu M$ each), and $5 \mu \mathrm{L}$ of sample $(0.5 \mathrm{ng}$ of $\mathrm{cDNA} / \mu \mathrm{L})$.

The relative gene expression was determined using HPRT1, PGK1, and RPS9 as endogenous control genes, which were expressed in all samples. Gene expression was analyzed from raw cycles to threshold $\left(\mathbf{C}_{\mathbf{T}}\right)$ values obtained using Data Assist software (Applied Biosystems) and then corrected for efficiency using the formula $\mathrm{C}_{\text {Tcorrected }}=-\log _{2}\left(\mathrm{E}^{-\mathrm{C}_{\mathrm{T}}}\right)$. The computation of $\Delta \mathrm{C}_{\mathrm{T}}$ for genes of interest pre- and postinfusion was calculated using the corrected $\mathrm{C}_{\mathrm{T}}$ values for genes of interest and the mean of the corrected $\mathrm{C}_{\mathrm{T}}$ for the control genes, which included HPRT1, PGK1, and RPS9I, according to the formula $\Delta \mathrm{C}_{\mathrm{T}}=\mathrm{C}_{\mathrm{T} \text { Target gene pre or postinfusion }}$

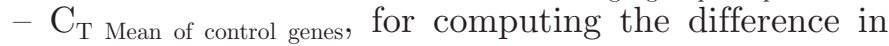
expression after infusion was used the following formula: $\Delta \Delta \mathrm{C}_{\mathrm{T}}=\Delta \mathrm{C}_{\mathrm{T} \text { Target gene postinfusion }}-\Delta \mathrm{C}_{\mathrm{T} \text { Target gene preinfusion }}$

\section{Statistical Analysis}

Feeding behavior, intake, metabolite and hormone responses, yield of milk and milk components, and concentration of milk components were analyzed using the
Fit Model procedure of JMP (version 12.0, 2015; SAS Institute Inc., Cary, NC) with the following model:

$$
Y_{i j k l}=\mu+S_{i}+S\left(C_{j}\right)_{i}+S\left(P_{k}\right)_{i}+T_{l}+e_{i j k l},
$$

where $Y_{i j k l}=$ the dependent response variable of interest, $\mu=$ overall mean, $S_{i}=$ random effect of square $(i$ $=1$ to 2$), S\left(C_{j}\right)_{i}=$ random effect of cow within square $(j=4), S\left(P_{k}\right)_{i}=$ fixed effect of period within square $(k$ $=1$ to 4$), T_{l}=$ fixed effect of treatment ( $l=1$ to 4$)$, and $e_{i j k l}=$ residual, normally distributed. Treatment effects were declared significant at $P \leq 0.05$ and tendencies for treatment effects at $P \leq 0.10$. Interactions were declared significant at $P \leq 0.10$ and tendencies for interactions at $P \leq 0.15$. All data are expressed as least squares means (LSM) and standard error of the mean, unless otherwise specified. Contrasts were conducted between each infusion treatment and the control treatment.

The $\Delta \mathrm{C}_{\mathrm{T}}$ and $\Delta \Delta \mathrm{C}_{\mathrm{T}}$ values were analyzed with the following model using the Fit Model procedure of JMP (version 12.0, 2015; SAS Institute Inc.):

$$
Y_{i j k l}=\mu+S_{i}+S\left(C_{j}\right)_{i}+S\left(P_{k}\right)_{i}+T_{l}+e_{i j k l},
$$

where $Y_{i j k l}=$ the $\Delta \mathrm{C}_{\mathrm{T}}$ of the gene of interest in each observational unit, $\mu=$ overall mean, $S_{i}=$ fixed effect of square $(i=1$ to 2$), S\left(C_{j}\right)_{i}=$ random effect of cow within square $(j=4), S\left(P_{k}\right)_{i}=$ random effect of period within square ( $k=1$ to 4$), T_{l}$ = fixed effect of treatment $(l=1$ to 4$)$, and $e_{i j k l}=$ residual, normally distributed. Treatment effects were declared significant at $P \leq 0.05$ and tendencies for treatment effects at $P \leq$ 0.10 . Interactions were declared significant at $P \leq 0.10$ and tendencies for interactions at $P \leq 0.15$. All data are expressed as LSM \pm standard error of the mean, unless otherwise specified. This model is equivalent to the model described by Steibel et al. (2009). Results are presented as fold changes relative to the CON samples. These were calculated from difference in LSM differences according to the formula $2^{\text {-diff }}$, where diff $=$ $\operatorname{LSM}_{\text {(treatment) }}-\mathrm{LSM}_{(\mathrm{CON})}$ (i.e., it is the difference in the LSM obtained from the mixed model). After analysis, $P$ values for treatment effect were subject to Multiple Test correction using a local false discovery rate value $<0.05$.

Eight cows started the experiment; however, one cow from the second block was removed from the study due to displaced abomasum during the first period and all data from this animal were excluded before statistical analysis. That cow was replaced with a spare, which followed the subsequent treatments within its sequence 
beginning with the second period, skipping glucose infusion.

\section{RESULTS}

\section{Feed Intake and Feeding Behavior}

Results for feed intake and feeding behavior are reported in Table 2. Propionic acid and LA decreased DMI compared with CON, whereas GLU had no effect. Lactic acid decreased DMI by $14 \%$ (16.3 vs. $18.9 \mathrm{~kg} / \mathrm{d}$, $P=0.02)$ by decreasing meal size by $20 \%$ (1.38 vs. 1.72 $\mathrm{kg}, P=0.04$ ), whereas PA decreased DMI by $24.3 \%$ $(14.3$ vs. $18.9 \mathrm{~kg} / \mathrm{d}, P<0.001)$ by tending to decrease the number of meals per day (10.6 vs. 12.3 meals; $P=$ 0.09). Similarly, LA and PA decreased digestible energy intake by 15 and $22 \%$, respectively, compared with CON and decreased MEI from the diet by 15 and $21 \%$, respectively, compared with CON. However, only PA infusion decreased total MEI including ME from the infusions and the ME from the diet compared with CON; PA decreased MEI 13.2\% compared with CON (34.8 vs. $40.1 \mathrm{Mcal} / \mathrm{d} ; P=0.04)$. Treatments had no residual effect on DMI on rest days compared with CON $(P>$ 0.05 , data not shown).

Infusion treatments did not affect any other feeding behavior variable compared with CON (Table 2).
Glucose infusion tended $(P=0.07)$ to decrease water intake and LA and PA decreased $(P=0.02$ and $P \leq$ 0.0001 , respectively) water intake compared with CON. Propionic acid decreased $(P=<0.01)$ the number of drinking bouts per day compared with CON.

\section{Milk Production and Components}

Milk yield averaged $37.5 \mathrm{~kg} / \mathrm{d}$ and no differences were observed between infusion and CON treatments $(P>0.50 ;$ Table 3$)$. A tendency was observed for PA to increase the true protein content in milk $(P=0.07$, 3.11 vs. $2.87 \%)$, true protein yield $(P=0.10,1.19$ vs. $1.08 \mathrm{~kg} / \mathrm{d})$, and milk urea nitrogen concentration in milk $(P=0.10,9.68$ vs. $8.38 \mathrm{mg} / \mathrm{dL})$ compared with CON. Lactic acid tended to decrease lactose yield $(P=$ 0.08, 1.56 vs. $1.70 \mathrm{~kg} / \mathrm{d}$ ) compared with CON.

\section{Hepatic Acetyl CoA Content and Plasma Hormones and Metabolites}

Results for hepatic AcCoA content and plasma concentration of hormones and metabolites before and after infusion, and the differences between them are shown in Table 4 . After $22 \mathrm{~h}$ of infusion, GLU tended to decrease $(P=0.10,8.5 \mathrm{nmol} / \mathrm{g})$ and LA decreased $(P=0.04,11.1 \mathrm{nmol} / \mathrm{g})$ liver AcCoA content compared

Table 2. Effects of isoenergetic ${ }^{1}$ intra-abomasal infusion of glucose (GLU), lactic acid (LA), and propionic acid (PA) relative to a no-infusion control $(\mathrm{CON})$ on feeding behavior and energy intake for cows in the immediate postpartum period

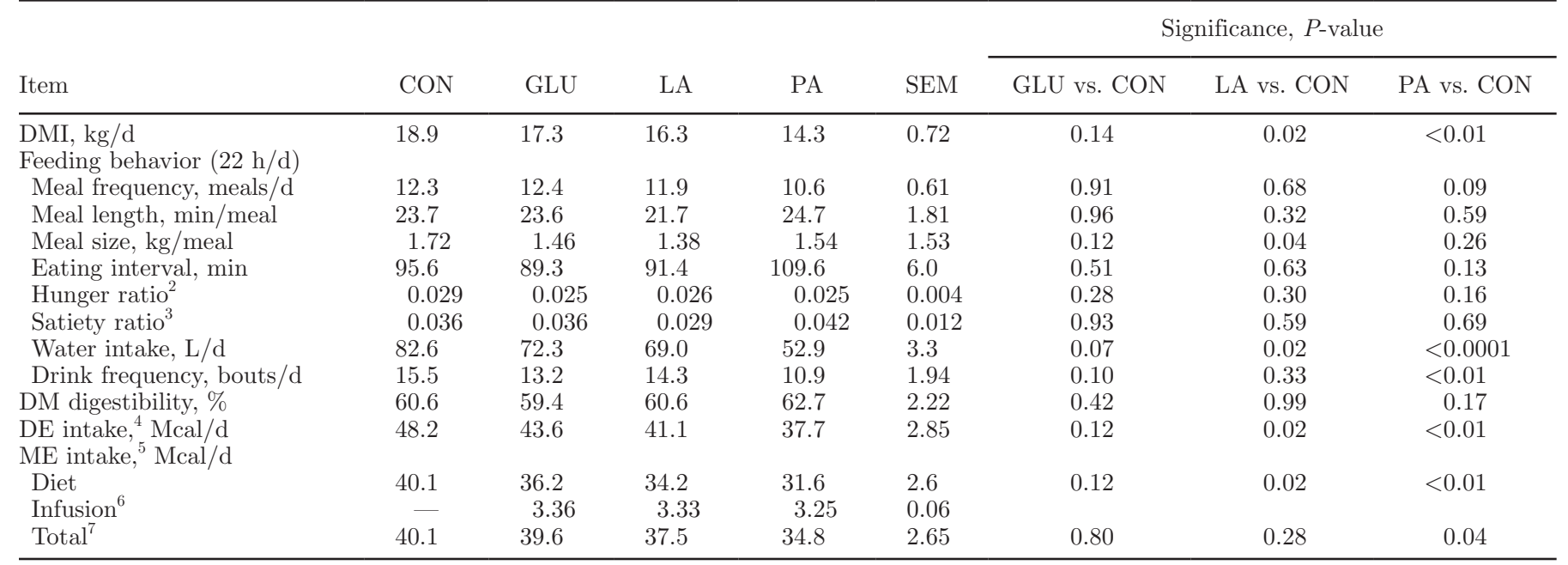

${ }^{1}$ Isoenergetic infusion, $151 \mathrm{kcal} / \mathrm{h}$.

${ }^{2}$ Hunger ratio $=$ weight of meal $/$ premeal interval.

${ }^{3}$ Satiety ratio $=$ weight of meal $/$ postmeal interval.

${ }^{4}$ Digestible energy $(\mathrm{DE})$ intake $(\mathrm{Mcal} / \mathrm{d})=$ gross energy $(\mathrm{GE})$ intake - GE feces.

${ }^{5} \mathrm{ME}$ intake from the diet was calculated according to NRC $(2001)$. ME $(\mathrm{Mcal} / \mathrm{kg})=1.01 \times(\mathrm{DE}-0.45) . \mathrm{ME}$ intake $(\mathrm{Mcal} / \mathrm{d})=\mathrm{ME} \times \mathrm{DMI}$. ${ }^{6} \mathrm{ME}$ from the infusion was based on energy density of $0.673 \mathrm{Mcal} / \mathrm{mol}$ of ME (Emery and Benedict, 1911) for GLU; 0.321 Mcal/mol (Saville and Gundry, 1959) for LA; and $0.365 \mathrm{Mcal} / \mathrm{mol}$ (Labedeva, 1964) for PA.

${ }^{7}$ Total ME intake $=\mathrm{ME}$ intake diet $+\mathrm{ME}$ infusion. 
Table 3. Effects of intra-abomasal infusion of propionic acid (PA), lactic acid (LA), and glucose (GLU) relative to a control (CON) with no infusion on milk yield and milk components over the $22 \mathrm{~h} / \mathrm{d}$ infusion for cows in the immediate postpartum period for isoenergetic infusions ${ }^{1}$

\begin{tabular}{|c|c|c|c|c|c|c|c|c|}
\hline \multirow[b]{2}{*}{ Item } & \multicolumn{4}{|c|}{ Infusion } & \multirow[b]{2}{*}{ SEM } & \multicolumn{3}{|c|}{ Significance, $P$-value } \\
\hline & $\mathrm{CON}$ & GLU & LA & PA & & GLU vs. CON & LA vs. CON & PA vs. CON \\
\hline Fat yield, $\mathrm{kg} / \mathrm{d}$ & 1.68 & 1.59 & 1.47 & 1.77 & 0.109 & 0.61 & 0.21 & 0.61 \\
\hline True protein, \% & 2.87 & 2.70 & 2.70 & 3.11 & 0.145 & 0.42 & 0.56 & 0.07 \\
\hline True protein yield, $\mathrm{kg} / \mathrm{d}$ & 1.08 & 1.13 & 0.99 & 1.19 & 0.043 & 0.55 & 0.16 & 0.10 \\
\hline Solids, \% & 5.45 & 5.38 & 5.21 & 5.50 & 0.258 & 0.81 & 0.37 & 0.58 \\
\hline $\mathrm{TS}, \mathrm{kg} / \mathrm{d}$ & 1.98 & 1.97 & 1.97 & 2.00 & 0.010 & 0.90 & 0.92 & 0.86 \\
\hline MUN, mg/dL & 8.38 & 9.40 & 8.87 & 9.68 & 2.02 & 0.22 & 0.52 & 0.10 \\
\hline
\end{tabular}

${ }^{1}$ Isoenergetic infusion, $151 \mathrm{kcal} / \mathrm{h}$.

with CON, but PA had no effect compared with CON. All 3 infusion treatments increased plasma insulin concentration compared with control. Infusion of GLU had the greatest effect, more than doubling plasma insulin concentration by $0.22 \mu \mathrm{g} / \mathrm{L}(P<0.0001)$, whereas LA and PA increased plasma insulin concentration by 0.05 $\mu \mathrm{g} / \mathrm{L}(P=0.03)$ and $0.06 \mu \mathrm{g} / \mathrm{L}(P=0.02)$, respectively. Glucose infusion decreased plasma glucagon concentration by $9.7 \mathrm{pg} / \mathrm{mL}$ and the change was different from the CON treatment $(P=0.04)$, which increased plasma

Table 4. Effect of intra-abomasal isoenergetic infusions (151 kcal/h) of propionic acid (PA), lactic acid (LA), and glucose (GLU) relative to a control $(\mathrm{CON})$ with no infusion on plasma concentrations of insulin, glucagon, metabolites, and liver acetyl CoA (AcCoA) content before infusion, after infusion, and change over the $22 \mathrm{~h} / \mathrm{d}$ infusion for cows in the immediate postpartum period

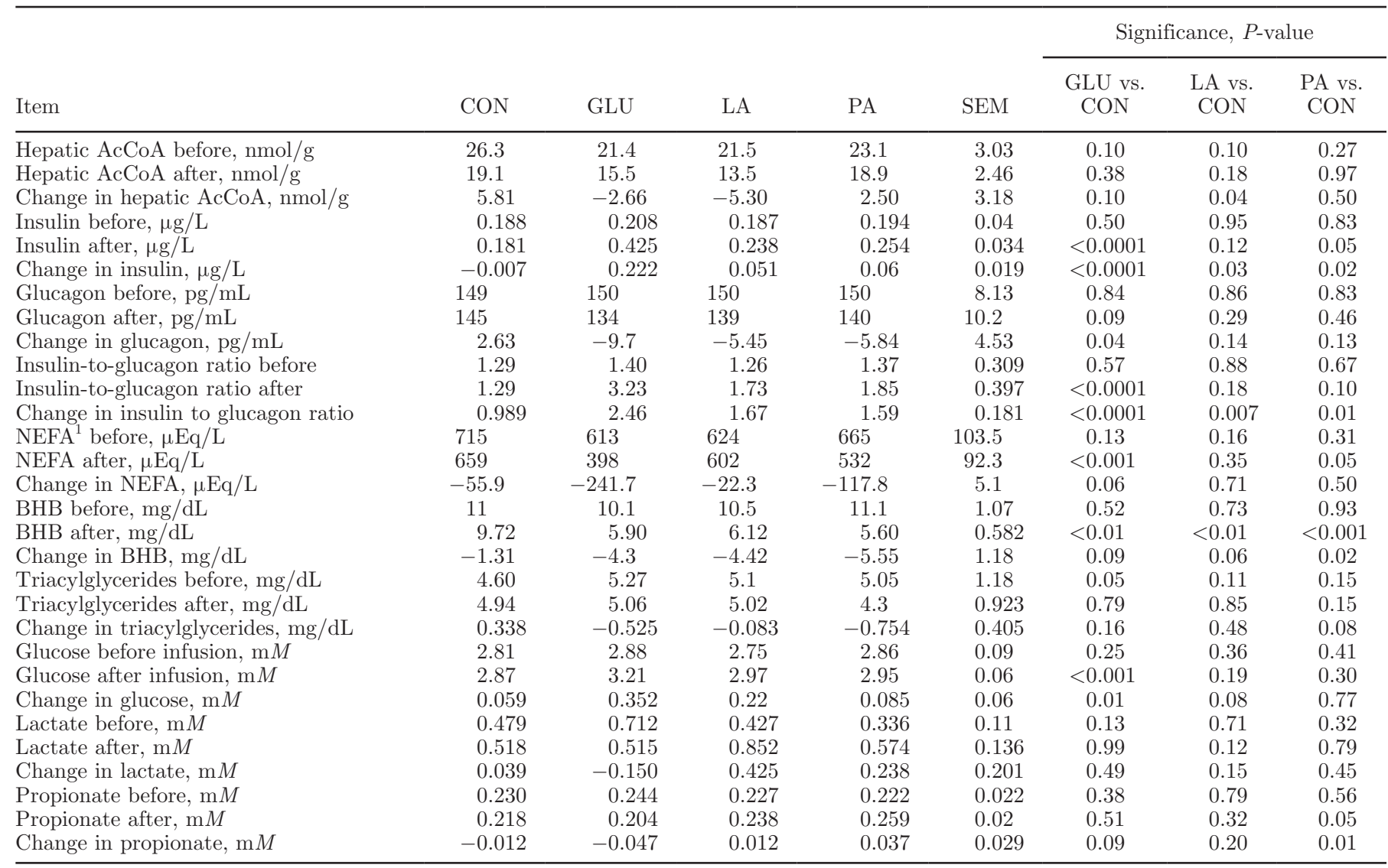

${ }^{1} \mathrm{NEFA}=$ nonesterified fatty acids. 
glucagon concentration. The decrease in glucagon concentration for LA and PA infusions were not different from CON treatment.

Glucose treatment decreased plasma NEFA concentration by $242 \mu \mathrm{Eq} / \mathrm{L}$, which tended to differ from CON $(P=0.06)$ in which plasma NEFA concentration decreased $56 \mu \mathrm{Eq} / \mathrm{L}$, whereas LA and PA did not differ from CON (Table 4). Propionic acid treatment decreased plasma BHB by $5.8 \mathrm{mg} / \mathrm{dL}$, which was greater $(P=0.02)$ than the change for CON of $1.3 \mathrm{mg} / \mathrm{dL}$ and both GLU and LA decreased plasma BHB by $\sim 4.4 \mathrm{mg} /$ $\mathrm{dL}$, which tended to be greater than the change for CON $(P \leq 0.09$; Table 4$)$.

Treatment infusions did not affect plasma concentrations of acetate or lactate compared with CON (Table 4). However, PA infusion $(P=0.01)$ increased plasma propionate concentration, and GLU tended to decrease plasma propionate concentration $(P=0.09)$ compared with CON. Glucose treatment increased $(P<0.01)$ and LA infusion tended to increase $(P=0.08)$ plasma glucose concentration compared with CON.

\section{Hepatic Gene Expression}

Effects of treatment on $\mathrm{C}_{\mathrm{T}}$ differences after infusion relative to before infusion are reported in Supplemental Table S2 (https://doi.org/10.3168/jds.2017-13607). Fold changes on hepatic genes affected by infusion treatments and the confidence intervals for the fold changes are reported in Supplemental Tables S3 and S4, respectively (https://doi.org/10.3168/jds.2017 -13607). Infusion treatments increased hepatic expression of glutamate dehydrogenase 1 (GLUD1), glycerol3-phosphate acyltransferase $(G P A M)$, and phosphoenolpyruvate carboxykinase 1 ( $P C K 1$ ) compared with CON (false discovery rate value $<0.05$ ). Relative mRNA abundance of GLUD1 was increased 4.0-fold by GLU $(P=0.01), 3.3$-fold by PA $(P=0.02)$, and 2.7 fold by LA $(P=0.04)$ compared with CON. Relative mRNA abundance of GPAM was increased 3.1-fold by LA $(P=0.01), 2.5$-fold by GLU $(P=0.01)$, and 2.0 fold by PA $(P=0.05)$ compared with CON. Relative mRNA abundance of $P C K 1$ was increased 6.0 -fold by GLU $(P=0.03)$ and 5.4 -fold by PA $(P=0.03)$ but was not affected by LA compared with CON (Supplemental Table S3; https://doi.org/10.3168/jds.2017-13607). Changes in hepatic expression of fructose-1,6-bisphosphatase (FBP1), aspartate aminotransferase (GOT2), pyruvate carboxylase $(P C)$, propionyl-CoA carboxylase $\alpha(P C C A)$, and peroxisome proliferator activated receptor $\alpha(P P A R A)$ were considered as potential (false discovery rate $<0.10$ ) hepatic genes affected by infusion of fuels and results are reported in the supplemental material (Supplemental Table S3; https://doi.org/10 $.3168 /$ jds.2017-13607).

\section{DISCUSSION}

Our results indicate that fuels derived from ruminal fermentation and intestinal digestion of starch result in different effects on DMI and MEI of cows in the PP period compared with a sham control consistent with their expected effects on hepatic oxidation. According to the HOT, anaplerotic fuels extracted by the liver may promote oxidation of $\mathrm{AcCoA}$ and contribute to satiety (Allen et al., 2009). Of the fuels produced from the fermentation and digestion of starch, propionate is expected to stimulate hepatic oxidation to the greatest extent because it is efficiently extracted from the blood by the liver and is obligatorily anaplerotic, stimulating tricarboxylic acid (TCA) cycle activity and oxidation of AcCoA (Allen, 2014). Therefore, the greater reduction in DMI and MEI by PA compared with CON among treatments was expected. Although the change in hepatic AcCoA content over the 22-h infusion period was similar for $\mathrm{PA}$ compared with $\mathrm{CON}$, entry and oxidation in the TCA cycle was likely greater for PA compared with CON because PA decreased BHB concentration in plasma but not NEFA concentration compared with CON. Additionally, pulse doses of PA decreased hepatic AcCoA content at 30 and $60 \mathrm{~min}$ postdosing and changes in AcCoA content over a day do not reflect changes relative to meals as discussed by Gualdrón-Duarte and Allen (2017).

Intraruminal continuous infusion of PA decreased DMI and MEI of cows in the PP period by decreasing meal size with no effect on meal frequency compared with acetic acid (Stocks and Allen, 2013). Whereas we expected PA to reduce meal size compared with CON, the effect of PA on meal size was not significant and the reduction in DMI and MEI was from combination of a numerical reduction of $11 \%$ in meal size and a tendency for a $14 \%$ decrease in meal frequency compared with CON.

The hypophagic effects of propionate compared with acetate have been well established by previous experiments reported in the literature as reviewed by Allen (2000). Whereas isomolar amounts of propionate and acetate were generally infused, propionate has greater ME per mole than acetate, and the effects on total MEI accounting for the ME infused were not measured in most studies. However, propionate also decreased total MEI from the diet and treatment infusions in lactating cows compared with acetate when infused intraruminally (Oba and Allen, 2003b). Although both PA and acetic acid can be produced by fermentation of 
starch, we did not include acetic acid as a treatment in the present experiment because increased grain feeding increases ruminal production of PA (Bauman et al., 1971; Sutton et al., 2003) with little effect on acetic acid production (Davis, 1967; Sutton et al., 2003), and because its effects on DMI compared with PA have been established previously (Allen, 2000). The effects of propionate and acetate on feed intake are consistent with the HOT because little acetate is extracted from the blood by the liver (Knapp et al., 1992) and acetate is not anaplerotic and cannot stimulate hepatic oxidation.

The importance of the anaplerotic effects of fuels was demonstrated by a study in which PA decreased DMI and MEI of cows in the PP period compared with isoenergetic infusion of glycerol (Gualdrón-Duarte and Allen, 2017). Whereas glycerol is potentially anaplerotic, its anaplerotic effect is likely greatly diminished when glucose demand is high in the PP period, entering the gluconeogenic pathway in the cytosol instead of stimulating hepatic oxidation and satiety (GualdrónDuarte and Allen, 2017). Lactate also is anaplerotic, entering the TCA cycle as oxaloacetate through pyruvate, and can also stimulate oxidation of AcCoA. In support of this, we found that LA infusion decreased hepatic $\mathrm{AcCoA}$ content and tended to decrease plasma BHB concentration. Extraction of lactate from the blood by the liver is greatest in the PP period and declines as lactation progresses, but its extraction is much less than propionate (Reynolds et al., 2003). In addition, pyruvate from lactate might be used for alanine conversion through transamination. Therefore, the reduction in DMI by LA compared with control was expected. Whereas LA reduced DMI compared with CON, the effect was not adequate to significantly reduce MEI when the ME of the diet and infusate were combined. The reduction in DMI was from a reduction in meal size indicating that its effect was during the timeframe of meals. The LA treatment tended to increase glucose, consistent with its use as a glucose precursor and increased plasma insulin concentration. Plasma propionate concentration was increased $17 \%$ by PA over the 22-h infusion, but plasma lactate concentration was doubled (numerical only) consistent with their expected efficiency of hepatic extraction from the blood.

Infusion of GLU did not affect DMI or MEI compared with CON, consistent with previous experiments with midlactation cows in which glucose was infused postruminally (Frobish and Davis, 1977; Clark et al., 1977) or intravenously (Dowden and Jacobson, 1960; Al-Trad et al., 2009) in dairy cows. The ruminant liver extracts little glucose from the blood (Stangassinger and Giesecke, 1986) because activities of glucokinase and hexokinase are low (Emmanuel, 1981). Therefore, glucose is unable to stimulate hepatic oxidation directly and its effect on DMI compared with CON was as expected. Although a significant effect of GLU on DMI compared with CON was not detected, the numerical reduction in DMI is likely the reason for the lack of effect of GLU on MEI compared with CON because the numerical reduction in MEI of the diet that was similar to the amount of ME infused per day. Whereas we did not detect a reduction of DMI by GLU treatment, infusion of graded amounts of glucose (0 to $1,500 \mathrm{~g} / \mathrm{d})$ into the duodenum of lactating cows $(\sim 60 \mathrm{~d} P \mathrm{PP})$ decreased DMI linearly, but did not affect $\mathrm{NE}_{\mathrm{L}}$ intake when the infused glucose was considered (Hurtaud et al., 1998) and infusion of $1,500 \mathrm{~g}$ of starch hydrolysate into the rumen or abomasum reduced DMI but increased NE intake of cows in early lactation (24 to $66 \mathrm{~d} \mathrm{PP}$ ) when the infused glucose was considered (Knowlton et al., 1998). Variation in effects of glucose infusions on DMI and MEI might be from differences in the dose of glucose, physiological state of cows, differences in diet composition, and length of infusion. Although, the above experiments were not conducted during the PP period, continuous infusion of glucose $(1,500 \mathrm{~g} / \mathrm{d})$ into the abomasum of cows from 4 to 29 DIM decreased DMI $\sim 6 \mathrm{~kg} / \mathrm{d}$ (Larsen and Kristensen, 2009). We also infused during the PP period but infused a lower dose $(\sim 60 \%)$ for only one day. Differences for the effects of glucose infusion between these experiments might be because treatment had a greater effect on increasing plasma insulin concentration for a longer time, which might have downregulated gluconeogenesis, decreasing cataplerosis of the TCA cycle, increasing TCA cycle activity and oxidation of AcCoA, and stimulating satiety sooner, as discussed by Brown and Allen (2013). Effects of glucose infusion on meal size and DMI were dependent upon the diet in an experiment in which glucose was infused at a rate of $1,000 \mathrm{~g} / \mathrm{d}$ for the first 12 d PP (Brown and Allen, 2013). Therefore, depression of DMI by glucose might be related to its indirect effects on hepatic oxidation, dependent on dose, diet, and physiological state of cows.

Increased expression of hepatic GPAM, the gene coding for the enzyme responsible for the first and committed step in glycerolipid synthesis, by all infusion treatments was consistent with effects on increasing plasma insulin concentration because SREBF1 (Mughal et al., 2010), a nuclear factor that upregulates GPAM expression, is induced by insulin. Infusion of GLU and PA increased expression of hepatic PCK1 despite increasing plasma insulin concentration. Insulin has been reported to decrease mRNA abundance of $P C K 1$ in rat liver 
cells (Granner et al., 1983) and glucose infusion in cows numerically increased blood insulin concentration $54 \%$ and decreased hepatic mRNA abundance of PCK1 51\% compared with water infusion, although the treatments were not directly compared statistically (Zhang et al., 2015). However, in that study hepatic PCK1 expression was maintained when serum insulin concentration was almost doubled in cows infused with propionate (Zhang et al., 2015). Differences in effects of propionate and glucose infusion on $P C K 1$ expression between the current experiment and the experiment of Zhang et al. (2015) might be because we infused propionate and glucose at twice the rate $(0.41$ and $0.22 \mathrm{~mol} / \mathrm{h}$, compared with 0.21 and $0.11 \mathrm{~mol} / \mathrm{h}$, respectively), for a longer time ( 22 vs. $8 \mathrm{~h}$ ), to cows in the immediate $\mathrm{PP}$ period compared with mid lactation. Glutamate dehydrogenase 1 (GLUD1) converts L-glutamate into $\alpha$-ketoglutarate and plays a key role in anaplerosis of the TCA cycle. However, the mechanism by which all treatments increased its expression is not known. Although these effects of treatment on mRNA abundance of enzymes might have affected liver metabolism, individual reactions are also dependent on enzyme synthesis and activity as well as substrate availability.

\section{CONCLUSIONS}

Fuels supplied by the ruminal fermentation and intestinal digestion of starch have different effects on DMI that are consistent with their ability to stimulate hepatic oxidation of AcCoA. Greater ruminal starch fermentation increases the production of $\mathrm{PA}$, which decreased DMI and total ME compared with CON. However, the primary fuels from digestion of starch in the small intestine (glucose and lactate) did not decrease MEI of cows compared with CON. Depression of feed intake of cows in the PP period by diets containing highly fermentable starch is likely because of the ability of PA to stimulate hepatic oxidation.

\section{ACKNOWLEDGMENTS}

We acknowledge the financial support for this project from USDA National Research Initiative Competitive Grant no. 2014-67015-21708 to MSA, and from Fulbright Colombia and Colciencias (Bogota, Colombia) to LGD. We also thank D. G. Main, R. A. Longuski, J. Liesman, R. West, G. Maldini, K. Kennedy, R. Albornoz, R. Yair, and D. de Sousa (all from Michigan State University) for technical assistance; G. A. Contreras, C. Strider, Norma Manrique-Carpintero, and J. Landgraf for assistance on gene expression analysis; R. J. Tempelman and J. P. Steibel for statistical advice; and
Kemin Industries Inc. (Des Moines, IA) for supplying the propionic acid.

\section{REFERENCES}

Al-Trad, B., K. Reisberg, T. Wittek, G. B. Penner, A. Alkaassem, G. Gabel, M. Fürll, and J. R. Aschenbach. 2009. Increasing intravenous infusions of glucose improve body condition but not lactation performance in midlactation dairy cows. J. Dairy Sci. 92:5645-5658.

Albornoz, R. I., and M. S. Allen. 2016. Diet starch content and fermentability affects feed intake and milk yield of cows in the postpartum period. J. Anim. Sci. 94:362. https://doi.org/10.2527/ jam2016-0755.

Allen. M. S. 2000. Effects of diet on short-term regulation of feed intake by lactating dairy cattle. J. Dairy Sci. 83:1598-1624. https:// doi.org/10.3168/jds.S0022-0302(00)75030-2

Allen, M. S. 2014. Drives and limits to feed intake in ruminants. Anim. Prod. (Purwokerto) 54:1513-1524. https://doi.org/10.1071/ AN14478

Allen, M. S., B. J. Bradford, and M. Oba. 2009. Board-Invited Review: The hepatic oxidation theory of the control of feed intake and its application to ruminants. J. Anim. Sci. 87:3317-3334. https://doi .org/10.2527/jas.2009-1779

AOAC International. 1997. Official Methods of Analysis. 16th ed. AOAC International, Gaithersburg, MD.

Bauman, D. E., C. L. Davis, and H. F. Bucholtz. 1971. Propionate production in the rumen of cows fed either a control or high-grain, low-fiber diet. J. Dairy Sci. 54:1282-1287.

Bradford, B. J., and M. S. Allen. 2005. Phlorizin administration increases hepatic gluconeogenic enzyme mRNA abundance but not feed intake in late-lactation dairy cows. J. Nutr. 135:2206-2211.

Brown, W. E., and M. S. Allen. 2013. Effects of intrajugular glucose infusion on feed intake, milk yield, and metabolic responses of early postpartum cows fed diets varying in protein and starch concentration. J. Dairy Sci. 96:7132-7142.

Clark, J. H., H. R. Spires, R. G. Derrig, and M. R. Bennink. 1977. Milk production, nitrogen utilization and glucose synthesis in lactating cows infused postruminally with sodium caseinate and glucose. J. Nutr. 107:631-644.

Cochran, R. C., D. C. Adams, J. D. Wallace, and M. L. Galyean. 1986 Predicting digestibility of different diets with internal markers: Evaluation of four potential markers. J. Anim. Sci. 63:1476-1483.

Dado, R. G., and M. S. Allen. 1995. Intake limitations, feeding behavior, and rumen function of cows challenged with rumen fill from dietary fiber or inert bulk. J. Dairy Sci. 78:118-133. https://doi .org/10.3168/jds.S0022-0302(95)76622-X

Davis, C. L. 1967. Acetate production in the rumen of cows fed either control or low-fiber, high-grain diets. J. Dairy Sci. 50:1621-1625.

Dowden, D. R., and D. R. Jacobson. 1960. Inhibition of appetite in dairy cattle by certain intermediate metabolites. Nature 188:148 149.

Emery, A. G., and F. G. Benedict. 1911. The heat of combustion of compounds of physiological importance. Am. J. Physiol. 28:301307.

Emmanuel, B. 1981. Glucokinase, hexokinase, gluconeogenesis, glycogenesis and glycolysis in camel (Camelus dromedarius) and sheep (Ovis aries). Comp. Biochem. Physiol. B Biochem. Mol. Biol. 64:547-550

Frobish, R. A., and C. L. Davis. 1977. Effect of abomasal infusions of glucose and proprionate on milk yield and composition. J. Dairy Sci. 60:204-209.

Goering, H. K., and P. J. Van Soest. 1970. Forage fiber analysis (Apparatus, reagents, procedures, and some applications). Agric Handbook No. 379. ARS-USDA, Washington, DC.

Granner, D., T. Andreone, K. Sasaki, and E. Beale. 1983. Inhibition of transcription of the phosphoenolpyruvate carboxykinase gene by insulin. Nature 305:549-551.

Gualdrón-Duarte, L. B., and M. S. Allen. 2017. Increased anaplerosis of the tricarboxylic acid cycle decreased meal size and energy 
intake of cows in the postpartum period. J. Dairy Sci. 100:44254434. https://doi.org/10.3168/jds.2016-12104.

Hach, C. C., B. K. Bowden, A. V. Kopelove, and S. V. Brayton. 1987. More powerful peroxide Kjeldahl digestion method. J. Assoc. Off. Anal. Chem. 70:783-787.

Hurtaud, C., H. Rulquin, and R. Verite. 1998. Effects of graded duodenal infusions of glucose on yield and composition of milk from dairy cows. 1. Diets based on corn silage. J. Dairy Sci. 81:3239-3247.

Karkalas, J. 1985. An improved enzymic method for the determination of native and modified starch. J. Sci. Food Agric. 36:1019-1027.

King, M. T., and P. D. Reiss. 1985. Separation and measurement of short-chain coenzyme-A compounds in rat liver by reversedphase high-performance liquid chromatography. Anal. Biochem. 146:173-179.

Knapp, J. R., H. C. Freetly, B. L. Reis, C. C. Calvert, and R. L. Baldwin. 1992. Effects of somatotropin and substrates on patterns of liver metabolism in lactating dairy cattle. J. Dairy Sci. 75:10251035. https://doi.org/10.3168/jds.S0022-0302(92)77846-1.

Knowlton, K. F., T. E. Dawson, B. P. Glenn, G. B. Huntington, and R. A. Erdman. 1998. Glucose metabolism and milk yield of cows infused abomasally or ruminally with starch. J. Dairy Sci. 81:3248-3258.

Kotarski, S. F., R. D. Waniska, and K. K. Thurn. 1992. Starch hydrolysis by the ruminal microflora. J. Nutr. 122:178-190.

Labedeva, N. D. 1964. Heats of combustion of monocarboxilic acids. Russ. J. Phys. Chem. (Engl. Transl). 38:1435-1437.

Larsen, M., and N. B. Kristensen. 2009. Effect of abomasal glucose infusion on splanchnic amino acid metabolism in periparturient dairy cows. J. Dairy Sci. 92:3306-3318. https://doi.org/10.3168/ jds.2008-1889.

Larson, J., and P. C. Hoffman. 2008. Technical note: A method to quantify prolamin proteins in corn that are negatively related to starch digestibility in ruminants. J. Dairy Sci. 91:4834-4839. https://doi.org/10.3168/jds.2008-1378.

Mertens, D. R. 2002. Gravimetric determination of amylase-treated neutral detergent fiber in feeds with refluxing in beakers or crucibles: Collaborative study. J. AOAC Int. 85:1217-1240.

Mughal, R. S., J. L. Scragg, P. Lister, P. Warburton, K. Riches, D. J. O'Regan, S. G. Ball, N. A. Turner, and K. El Porter. 2010. Cellular mechanisms by which proinsulin C-peptide prevents insulin-in- duced neointima formation in human saphenous vein. Diabetologia 53:1761-1771. https://doi.org/10.1007/s00125-010-1736-6.

NRC. 2001. Nutrient Requirements of Dairy Cattle. 7th rev. ed. Natl. Acad. Press, Washington, DC.

Oba, M., and M. S. Allen. 2003a. Effects of corn grain conservation method on feeding behavior and productivity of lactating dairy cows at two dietary starch concentrations. J. Dairy Sci. 86:174183. https://doi.org/10.3168/jds.S0022-0302(03)73598-X.

Oba, M., and M. S. Allen. 2003b. Intraruminal infusion of propionate alters feeding behavior and decreases energy intake of lactating dairy cows. J. Nutr. 133:1094-1099.

Reynolds, C. K., P. C. Aikman, B. Lupoli, D. J. Humphries, and D. E. Beever. 2003. Splanchnic metabolism of dairy cows during the transition from late gestation through early lactation. J. Dairy Sci. 86:1201-1217. https://doi.org/10.3168/jds.S0022-0302(03)73704 $-7$.

Saville, G., and H. A. Gundry. 1959. The heats of combustion solution and ionization of lactic acid. Trans. Faraday Soc. 55:2036-2038.

Stangassinger, M., and D. Giesecke. 1986. Splanchnic metabolism of glucose and related energy substrates. Pages 347-366 in Control of Digestion and Metabolism in Ruminants. L. P. Milligan, W. L. Grovum, and A. Dobson, ed. Prentice Hall, Englewood Cliffs, NJ.

Steibel, J. P., R. Poletto, P. M. Coussens, and G. J. M. Rosa. 2009. A powerful and flexible linear mixed model framework for the analysis of relative quantification RT-PCR data. Genomics 94:146-152.

Stocks, S. E., and M. S. Allen. 2012. Hypophagic effects of propionate increase with elevated hepatic acetyl coenzyme A concentration for cows in the early postpartum period. J. Dairy Sci. 95:32593268. https://doi.org/10.3168/jds.2011-4991

Stocks, S. E., and M. S. Allen. 2013. Hypophagic effects of propionic acid are not attenuated during a 3-day infusion in the early postpartum period in Holstein cows. J. Dairy Sci. 96:4615-4623. https://doi.org/10.3168/jds.2013-6653

Sutton, J. D., M. S. Dhanoa, S. V. Morant, J. France, D. J. Napper, and E. Schuller. 2003. Rates of production of acetate, propionate, and butyrate in the rumen of lactating dairy cows given normal and low-roughage diets. J. Dairy Sci. 86:3620-3633.

Zhang, Q., S. Koser, B. Bequette, and S. Donkin. 2015. Effect of propionate on mRNA expression of key genes for gluconeogenesis in liver of dairy cattle. J. Dairy Sci. 98:8698-8709. 